\title{
JORGE DE LIMA E AS ARTES PLÁSTICAS
}

\section{Gênese Andrade}

Resumo Este ensaio trata da imagem na obra de Jorge de Lima, mais especificamente da relação entre poesia e artes plásticas em $O$ mundo do menino impossivel e Poemas negros, e traz também algumas considerações sobre as fotomontagens e pinturas realizadas pelo artista. Palavras-chave Jorge de Lima, Lasar Segall, poesia brasileira, fotomontagem, ilustração, pintura, artes plásticas.

Abstract This paper deals with image in Jorge de Lima's work, mainly with the relation between poetry and plastic arts in O mundo do menino impossível and Poemas negros; it offers as well some considerations on photomontage and paintings accomplished by the artist. Keywords Jorge de Lima, Lasar Segall, Brazilian poetry, photomontage, illustration, painting, plastic arts. 
Ninguém pense que o silêncio, o olhar vago e longínquo dos pintores diante de suas telas são realmente reclusões ausentes de literatura: passam-se no interior de toda esta encenação grandes discursos recalcados, lirismos, diálogos gritantes, grandes palavras que ficam coladas às tintas indelevelmente, nas exposiçōes permanentes dos museus. [Jorge de Lima, "Notas sobre pintura"]

\section{Poesia e visualidade *}

* Este ensaio, com alterações, é parte integrante de ANDRADE, Gênese. Imagens eloqüentes. A escritura plástica de poetas e artistas latinoamericanos. São Paulo, 2001. Tese (Doutorado em Língua Espanhola e Literaturas Espanhola e Hispano-Americana). FFLCH-USP.

I Em vários momentos, Oswald critica o poeta e exalta o prosador Jorge de Lima. Cf. "Prosa e poesia" Correio da Manhã , Rio de Janeiro, IO.8.1952. Reproduzido em ANDRADE, Oswald de. Obras completas. Telefonema. São Paulo: Globo, 1990, p. 362-3. Cf. tb. "Oswald de Andrade explica porque a Semana de Arte Moderna ocorreu em São Pau-
Perplexidade, incômodo e espanto constroem a trajetória dos leitores que percorrem a vida e a obra de Jorge de Lima e se deparam com sua pluralidade.

Médico, poeta, romancista, ensaísta, pintor e escultor, o caráter múltiplo de sua personalidade reflete-se na diversidade de sua produção, considerada por alguns críticos como descontínua, enquanto outros buscam estruturá-la em uma unidade impossível.

Às vezes o poeta é valorizado em detrimento do prosador, enquanto em outros momentos é o romancista que se sobrepõe ao poeta, aos olhos até mesmo de seus contemporâneos, como Oswald de Andrade.' Suas fotomontagens causam escândalo nos anos quarenta e a emergência da atividade do pintor chega a incomodar.

Diante da personalidade multifária, também sua obra poética se ramifica em vários caminhos. Alexei Bueno divide-a em quatro fases: neoparnasiana, modernista, católica e surrealista. Para Otto Maria Carpeaux, há uma correspondência entre a multiplicidade artística em geral e a amplitude poética em particular:

[...] se pode afirmar que as múltiplas atividades artísticas de Jorge de Lima correspondem a uma qualidade característica de sua poesia: a de alargar-se em círculos concêntricos cada vez mais amplos. ${ }^{3}$

Entre a linha reta e a circularidade, Alfredo Bosi aponta para o sucessivo e a mutação: "mutações de tema e de forma que marcam a linguagem de Jorge de Lima, poeta sucessivamente regional, negro, bíblico e hermético" 4

Seria possível ainda construir um arco do soneto ao poema longo, passando por rimas e metros diversos em direção ao verso livre - quanto à forma e do negrismo ao onirismo, passando pela poesia religiosa - quanto ao tema.

A visualidade, sob nosso ponto de vista, pode ser considerada como um fio 
condutor da produção limiana, responsável ao mesmo tempo por sua pluralidade artística e pela organicidade de sua obra, presença constante seja nas imagens construídas com palavras - ekphrasis (verbalização de textos reais ou fictícios não-verbais) ou enárgeia (pôr diante dos olhos) -, nas ilustrações realizadas em seus livros pelo próprio autor e por outros artistas, ${ }^{5}$ ou nas pinturas e fotomontagens - cuja menção é até redundante - que dão continuidade ao trabalho com as ilustrações e dialogam com sua escritura.

Temos assim, mais que linha, círculo ou arco, uma espiral, pois as fases ou facetas dialogam e ultrapassam fronteiras temporais: os temas da infância, do negrismo e da religiosidade, por exemplo, constituem obras de diferentes épocas e diversas formas de expressão - ele os retoma, revisita-os e os deixa dialogar. Sua poesia evoca as artes plásticas e as pinturas convocam os poemas.

Neste ensaio vamos abordar a relação entre poesia e visualidade em três de seus livros de poemas - O mundo do menino impossivel, Essa negra Fulô e Poemas negros - e também nas fotomontagens e pinturas.

\section{A visualização d'O mundo do menino impossivel}

Jorge de Lima cria um menino impossível que dialoga com o aluno de poesia de Oswald de Andrade e o menino experimental de Murilo Mendes. A poesia da infância se ergue e se faz visível com palavras, imagens e com a própria materialidade do livro cujo formato antecipa a preciosidade do conteúdo.

O mundo do menino impossivel foi publicado em 1927 (Rio de Janeiro: Rio Typographia), com poema, capa e ilustraçōes de Jorge de Lima, coloridas por seu irmão Hildebrando de Lima. Chama a atenção, na folha de rosto, que o título apareça como "O mundo impossível do menino" talvez uma inversão intencional para refletir a "desordem"

As imagens da capa - o desenho, infantilizado, que retrata o menino impossível de braços abertos - e do verso da folha de rosto - o desenho de um sol colorido, com a língua à mostra, envolvido por círculos multicores: roxo, verde, vermelho, azul e marrom - anunciam o que o poema enuncia em seus primeiros versos: as "duas únicas coisas novas desse mundo: o sol e as crianças"

Tanto as imagens criadas como a associação de elementos são típicas das crianças. Consistem na apresentação do mundo sob um olhar pseudo-infantil. O ponto de vista é metonímico: os animais, os brinquedos, a lua, as estrelas etc. $10^{n}$ Entrevista concedida a Heráclio Dias, publicada em Diário de Notícias, Rio de Janeiro, 24.I.I954. Reproduzida em AndRade, Oswald de. Obras completas. Os dentes do dragão. São Paulo: Globo, 1990,

p. 224-5. 2 Cf. "Nota editorial" In: LIMA, Jorge de. Poesia completa. Rio de Janeiro: Nova Aguilar, I997, p. II-3. 3 Carpeaux, Otto Maria. "Introdução" In: LIMA, Jorge de. Obra poética. Rio de Janeiro: Editora Getúlio Costa, I949, p. x. 4 BosI, Alfredo. História concisa da literatura brasileira. Ed. revista $\mathrm{e}$ aumentada. São Paulo: Cultrix, 1994, p. 452. 5 Seus livros de poemas $O$ mundo do menino impossivel (1927), Essa negra Fulô (1928), Vinte sonetos (1949) e As ilhas - poema vi do Canto Iv: "As aparições", de Invenção de Orfeu - (1952) têm capas e/ ou ilustrações realizadas por ele mes- 

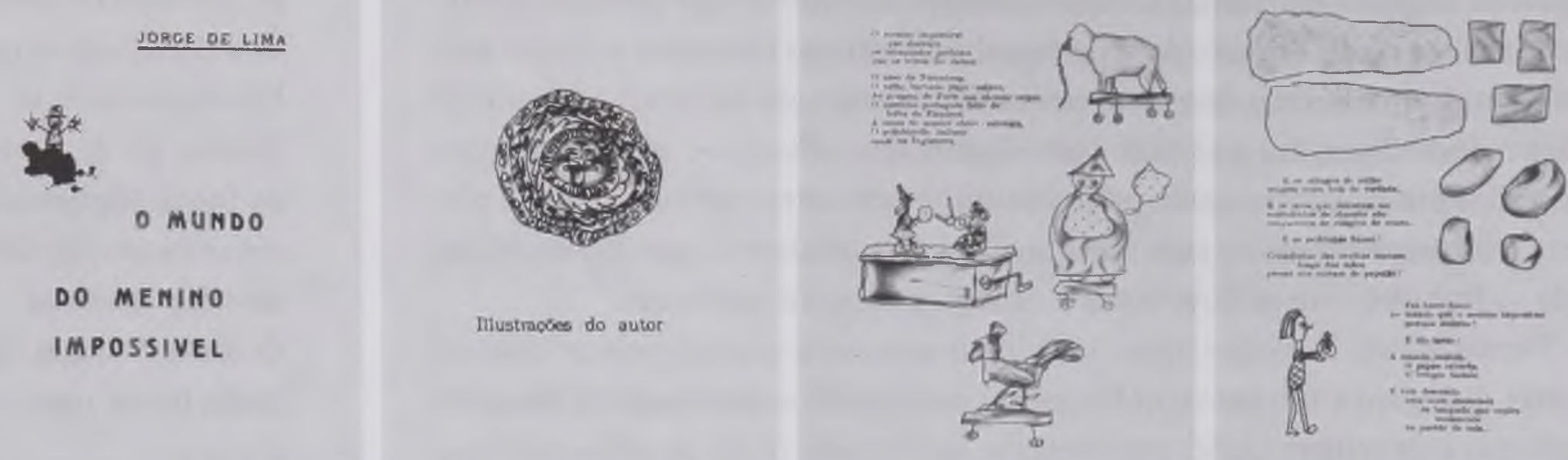

ACIMA

Capa, folha de rosto e duas páginas do livro O mundo do menino impossivel, Jorge de Lima, 1927

mo. Outros foram ilustrados por artistas diversos: Poemas escolhidos (1932), capa de Manuel Bandeira; Poemas negros (I947), ilustrações de Lasar Segall e Invenção de Orfeu (I952), capa e ilustrações de Fayga Ostrower. Alguns poemas publicados em jornais diversos e revistas foram ilustrados por Noemia, Guignard e Santa Rosa. Este último ilustrou também seus romances $O$ Anjo
Os desenhos, com traços bastante simples, representam alguns elementos do poema, predominantemente os brinquedos mencionados, e são pintados sem nenhuma analogia com o real, coloridos e alegres. Citemos um texto de I927, com o qual concordamos:

O colorido a lápis todo errado mas com a procura de acertar mais ainda mostra a criança. É de uma força enorme e dá uma notável realidade no desenho, isto é, na falta dele. ${ }^{6}$

O discurso também é pseudo-infantil. ${ }^{7}$ Destacam-se, no início, a antropomorfização e as antíteses: são atribuídas ações humanas às estrelas, à lua, aos ninhos e ao sol. O lusco-fusco, momento de encontro dos opostos dia/noite, permite a aproximação também das "primeiras estrelas" com os "derradeiros sinos" e "os últimos poetas"; "as velhas luas" opõem-se às "duas únicas/cousas novas/desse mundo:/O sol e as crianças". Há uma tentativa de abarcar o mundo.

É no cenário do anoitecer, simultaneamente tempo e espaço, que o menino impossível se destaca, pois enquanto tudo e todos dormem, inclusive as "crianças mansas", ele "ainda vela". A imagem do adormecimento é totalmente infantilizada pela forma como são apresentadas as aves — "Os ninhos vão dormir./Os pintinhos vão sonhar./O senhor D. Galo/deixa de galantear" - e as crianças "todas as crianças/mansas/dormem,/acariciadas/por 'Mãe-negra' Noite."

A referência à noite como "Mãe-negra" introduz a questão do nacional/popular em oposição ao elemento estrangeiro. O menino impossível destrói os brinquedos importados, que são reais, e faz prevalecer os elementos naturais e nacionais que sua imaginação, ou o faz-de-conta, transforma em brinquedos: 
O menino impossível

que destruiu até

os soldados de chumbo

de Moscou

e furou os olhos de um "Papá Noel"

brinca com sabugos de milho,

caixas vazias,

tacos de pau,

pedrinhas brancas do rio...

"Faz de conta que os sabugos

$$
\text { são bois..." }
$$

"Faz de conta...

"Faz de conta...

E os sabugos de milho

mugem como bois de verdade...

$E$ os tacos que deveriam ser

soldadinhos de chumbo são

cangaceiros de chapéus de couro...

Os desenhos nos fazem ver tanto os brinquedos reais como os imaginados e o mundo imaginário prolonga-se em seus sonhos, quando o anoitecer se impõe lentamente - uma "noite encantada" —, todos dormem e a lâmpada se apaga.

Após o texto, há um "Índice" fictício, lembremos que as páginas não estão numeradas, composto pela transcrição do poema em duas colunas. Na página seguinte, o "Índice das gravuras" também não pertence ao real, como o autor adverte com a frase "Faz de conta que são" a qual precede a enumeração dos títulos dos desenhos em uma ordem diversa à de sua sucessão no livro. Os brinquedos importados são aqui descritos em suas respectivas línguas, o que cria certa ironia no texto em confronto com os elementos brasileiros que vêm em seguida: "sabugos de milho, lampiões e cangaceiros do nordeste" A imagem da quarta capa, um desenho de Lampião, reitera a busca por realçar e reivindicar o elemento nacional presente no desenvolvimento do poema.

É possível analisar essa obra comparativamente a Primeiro caderno do aluno de poesia Oswald de Andrade, cuja publicação a antecede em alguns meses. No
(1934) e Guerra dentro do beco (1950).

6 LYs, Edmundo. "Joãocorta-pau e outras observaçōes (Sobre O mundo do menino impossivel, poema de Jorge de Lima)" Correio de Minas, Belo Horizonte, 30.12.1927, s.p. Realizamos a atualização ortográfica, quando necessário, dos textos citados.

7 No final do livro, porém, há um texto em latim, escrito com letra de forma manuscrita, com alguns espelhamentos, assinado "Jorge de Lima", que contrasta com esse discurso. 
8 Transcrevemos: "No dia Io de junho de 1927.

- Rio Tipographia da rua D. Petronilla n. 9 terminou a composição deste livro que o autor ilustrou e o aplicado aluno de desenho Hildebrando de Lima coloriu a lápis Faber. Foram tirados 300 exemplares numerados $\mathrm{e}$ rubricados pelo poeta $\mathrm{e}$ mais 2 em finíssima cambraia, destinados I a Oswald de Andrade e outro a Hildebrando de Lima, irmão mais novo do autor - prêmio por ter colorido estas páginas" 9 Nesse sentido, afirma Antônio Rangel Bandeira: "Essa epígrafe parecenos importantíssima para o estudo da poesia nordestina de Jorge de Lima. Com ela o poeta pretendeu estabelecer um traço de união entre Poemas e Novos poemas, quase insinuando que um não era senão uma continuação do outro. Revela, por outro lado, que sua atitude era ainda francamente modernista no sentido combativo da palavra. Ele sentia um cólofon, ${ }^{8}$ temos a referência direta a Oswald de Andrade e a expressão "o aplicado aluno de desenho" remete ao livro mencionado. O projeto de ambas é muito próximo: além de formatos semelhantes, têm em comum ilustrações pseudo-infantis, o uso do verso branco ou livre, a linguagem coloquial e a referência a elementos autobiográficos. A enumeração das brincadeiras que caracteriza o texto de Jorge de Lima está também em "Brinquedo" de Oswald, mas é apresentada paralelamente ao registro das transformações da cidade de São Paulo. O faz-de-conta, já mencionado, evoca o poema "Crônica": "Era uma vez/ O mundo" O repasse da meninice feito pelo poeta alagoano é um eco prolongado do que realiza o paulistano, de forma metonímica, em um poema que integra o conjunto "As quatro gares" intitulado "Infância": "O camisolão/ O jarro/O passarinho/O oceano/ A visita na casa que a gente sentava no sofá"

O mundo do menino impossível é comumente considerado pela crítica como auto-referencial, a questão da visualidade é desprezada e as metáforas são interpretadas como menções ao fazer poético: aquele que destrói os brinquedos importados para brincar com elementos autóctones, em um jogo de faz-de-conta, é lido como o poeta que nega a influência estrangeira e valoriza o nacional.

Essa leitura é provavelmente conduzida pelo fato de Jorge de Lima ter usado alguns versos do poema - “... o Menino Impossível quebrou todos os brinquedos que os vovôs lhe deram" - como epígrafe do livro Novos poemas, publicado em I929, o qual se caracteriza, de forma geral, por elementos nacionais e modernistas, como o uso da linguagem coloquial, o verso livre etc. ${ }^{9}$ Por reunir também essas características e ainda diferir totalmente do livro que o antecede - XIV alexandrinos (I9I4), constituído por sonetos parnasianos -, O mundo do menino impossivel acaba sendo considerado como o marco de sua adesão ao Modernismo. ${ }^{10}$

Sob nosso ponto de vista, este livro marca a ruptura com o passado e anuncia o que caracterizará a obra de Jorge de Lima: a presença do sonho, que predominará nos anos quarenta e cinqüenta, e a visualidade, que a permeará elementos que culminarão nas fotomontagens e quadros. Assim, pode ser considerado o mundo de Jorge de Lima em miniatura: retorno à infância, tema caro ao poeta, adesão ao Modernismo sem abrir mão do regional, faz-de-conta com palavras e imagens. 
Retratos em Essa negra Fulô e Poemas negros

Com seus poemas negristas, escritos a partir do final dos anos vinte, Jorge de Lima dialoga com Oswald de Andrade e os "Poemas da colonização" (Pau Brasil, I925) com Raul Bopp e Urucungo. Poemas negros (I932) e, no âmbito hispano-americano, com Ildefonso Pereda Valdés e La guitarra de los negros (1926), Nicolás Guillén e Motivos del son (1930), Luis Palés Mattos e Tuntún de pasa y grifería. Poemas afroantillanos (I937). ${ }^{\text {II }}$ Os textos limianos integram Poemas (1927), Essa negra Fulô (1928), Novos poemas (1929) e culminam em Poemas negros (1947). Os dois primeiros livros despertaram o interesse sobre sua obra no Uruguai e na Argentina, como demonstram as cartas dirigidas ao poeta alagoano por Ildefonso Pereda Valdés Pedro Juan Vignale e Enrique Mendez Calzada. ${ }^{12}$

Publicado em Maceió (Typ. da Casa Trigueiros), em tiragem limitada, Essa negra Fulô reúne o poema homônimo e "Bangüê" Embora não traga o crédito do autor da capa, atribuímo-la a Jorge de Lima com base em uma entrevista do autor, na qual afirma: "A capa de meu livro Bangüê foi desenhada por mim". ${ }^{13}$ Como não consta de sua bibliografia nenhuma obra com esse título e o poema mencionado, além da edição indicada, só será publicado posteriormente em Poemas negros, deduzimos que o poeta se refere, na verdade, àquela.

Nessa capa, vemos um desenho, pintado com a cor marrom, de um negro de costas ao lado do qual há uma pessoa de perfil, com um chicote na mão; a essa imagem sobrepõem-se cactos. Na quarta capa, no mesmo tom, temos a casa-grande. Tais imagens expressam o mesmo que os poemas que constituem o livro: a distância entre a casa-grande e a senzala, a apresentação dos castigos corporais a que os negros são submetidos, a presença do elemento negro na cultura brasileira.

Poemas negros, publicado no Rio de Janeiro pela editora Revista Acadêmica, reúne 40 textos - 37 poemas $^{14}$ e 3 textos em prosa - e I3 ilustrações de Lasar Segall. Quanto à escritura, de forma geral, o negro é apresentado pelo olhar do branco. São mostradas claramente suas condições de vida, aparece como dominado, reproduz-se sua fala, a oralidade, e se faz seu retrato por meio de sua cultura. Além da visualidade, destacam-se a musicalidade do "idioma afro-nordestino" - como Jorge de Sousa Araújo classificou o uso do vocabulário e expressões utilizados pelos negros africanos e seus descendentes que viviam ou vivem no Brasil's - e a evocação do olfato e do paladar na construção de seu retrato ou do cenário em que atua. especial prazer em apresentar-se como um menino impossível que mal acabara de quebrar os brinquedos que os vovôs lhe deram: a rima, a métrica, a estrutura parnasiana do verso" BANDEIRA, Antônio Rangel. Jorge de Lima: o roteiro de uma contradição. Rio de Janeiro: Livraria São José, I959, p. 4I. Io Cf. SANTA CRUZ, Luís. "Um poeta e duas cristandades" In: lima, Jorge de. Poesia completa. Op. cit., p. I3I-2. Antônio Rangel Bandeira interpreta o poema como uma "ação nacionalista" uma "declaração de independência poética e política" Cf. BANDEIRA, Antônio Rangel, op. cit., p. 33. II Para um estudo detalhado desse tema, cf. SCHWARTZ, Jorge. “Negrismo e negritude" In: Vanguardas latino-americanas. Polêmicas, manifes. tos e textos críticos. São Paulo: Edusp/ Iluminuras/ Fapesp, 1995, p. 579-604. 12 Os recortes dessas cartas foram encontrados 
À DIREITA

Ilustrações de Lasar

Segall para o livro

Poemas negros, de Jorge

de Lima, 1947
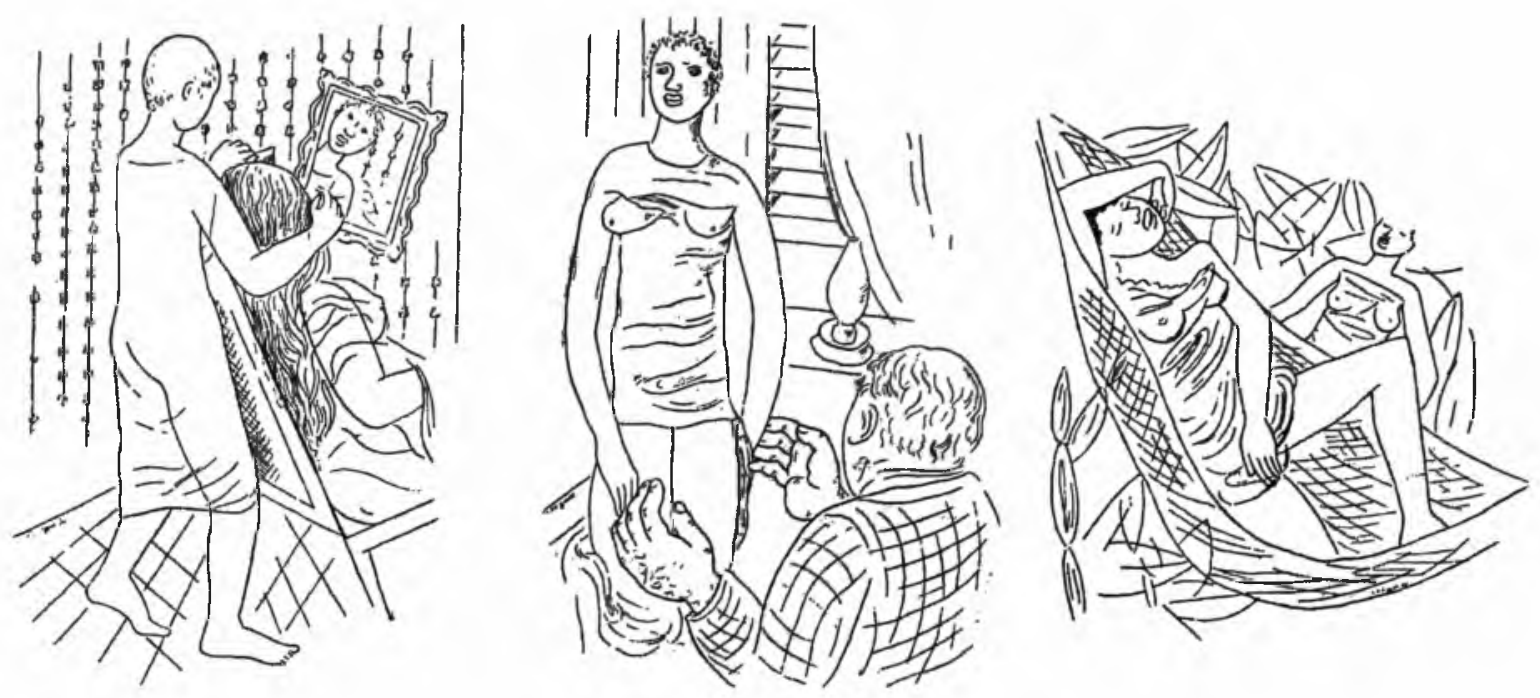

em um de seus álbuns

de recortes, que inte-

gram o acervo do Ar-

quivo Museu de Litera-

tura Brasileira da

Fundação Casa de Rui

Barbosa, no Rio de Ja-

neiro. Organizados pelo

próprio Jorge de Lima,

em torno de 20 , reú-

nem recortes de textos

de sua autoria ou sobre

sua obra publicados em

jornais e revistas.

I3 "A poesia não pára, é

a vida", entrevista a

Martins D'Alvarez, pu-

blicada em Dom Cas-

murro. Não temos a re-

ferência completa dessa

publicação. Consulta-

mo-la em um dos men-

cionados álbuns de re-

cortes do autor. Muitos

dos recortes, porém,
Gilberto Freyre, no prefácio ao livro, apresenta suas principais características:

Jorge de Lima, um dos maiores poetas brasileiros de todos os tempos, enriquece o brasileiro das áreas menos coloridas pela influência africana, com a expressão poética de sua experiência de nordestino de bangüê nascido e criado perto dos últimos "pombais negros" de que falou Nabuco. Ao mesmo tempo ele põe o estrangeiro que se aproxima da poesia brasileira em contato com uma das nossas maiores riquezas: a interpretação de culturas, entre nós tão livre, ao lado do cruzamento de raças. Dois processos através dos quais o Brasil vai se adoçando numa das comunidades mais genuinamente democráticas e cristãs do nosso tempo. ${ }^{16}$

Quanto às ilustrações, negristas, destacam-se o movimento, a sensualidade e a expressividade das figuras retratadas, essa última conseguida com a construção do primeiro plano, uma vez que seus rostos são pouco definidos e seu olhar é inexpressivo. No conjunto da obra de Lasar Segall, dão continuidade a sua proposta de retratar os problemas sociais e os desfavorecidos em uma atmosfera sombria. Como afirma Vera d'Horta:

No Brasil, o negro chama a sua atenção, e é grande a produção de desenhos, gravuras e de óleos em que explora seus traços exuberantes e marcados - o negro brasileiro simbolizava, para o expressionista recém-chegado, a encarnação do ser primitivo, exótico e marginalizado. ${ }^{17}$

Ao nos determos nos poemas ilustrados deste livro, podemos apontar a construção de retratos, cenários e cenas. Em "Essa negra Fulô" "Madorna de Iaiá" 


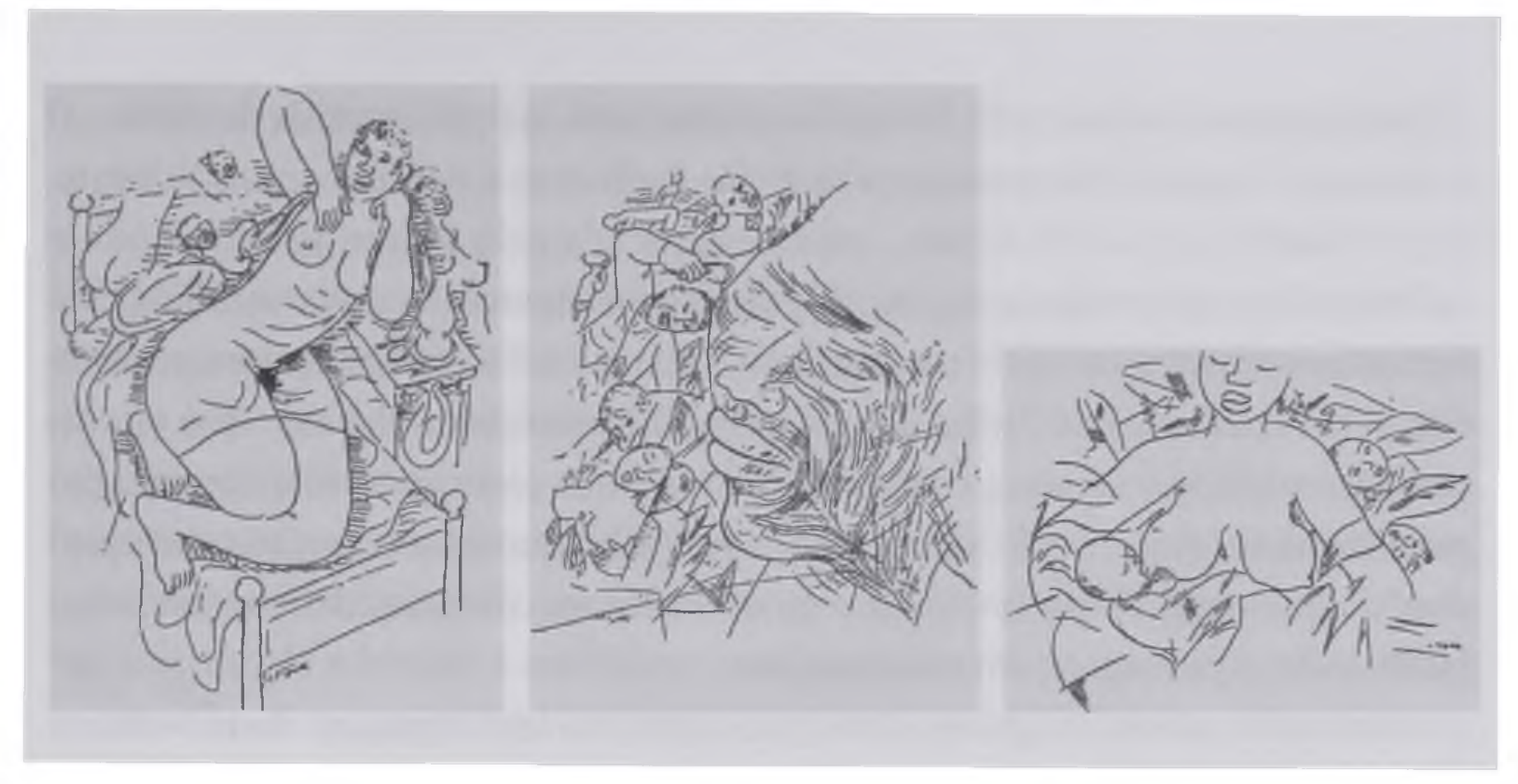

"Pai João" e "Joaquina maluca" temos retratos. Em "Baía de todos os santos", um cenário. "Cachimbo do sertão", "A noite desabou sobre o cais" e "Xangô" presentificam cenas. Vamos focalizar aqui os retratos.

O poema "Essa negra Fulô", que dá título ao primeiro livro mencionado, estrutura-se como uma paródia de uma história infantil e se podem ouvir aí três vozes: a da Fulô, a da Sinhá e a do narrador. Intercalam-se outras histórias que compõem o discurso proferido por Fulô, apresentado entre aspas. São histórias contadas para embalar o sono da Sinhá ou das crianças, transcritas com o registro da oralidade:

Ora, se deu que chegou

(isso já faz muito tempo)

no bangüê dum meu avô

uma nega bonitinha

chamada negra Fulô.

[...]

"Era um dia uma princesa que vivia num castelo que pissuía um vestido com os peixinho do má.

Entrou na perna dum pato saiu na perna dum pinto o Rei-Sinhô me mandou qui vos contasse mais cinco." [...] não trazem o título da publicação, a data ou página etc.

14 Quase todos os poemas já haviam sido publicados em livros anteriores de Jorge de Lima: Poemas (1927), Essa negra Fulô (1928), Novos poemas (1929), Poemas escolhidos (1932) e Tempo e eternidade (I935). I5 Cf. araújo, Jorge de Souza. Jorge de Lima e o idioma poético afronordestino. Maceió: Edufal, I983. I6 FREYRE, Gilberto. Prefácio a Poemas negros. Rio de Janeiro: Revista Acadêmica, I947. Reproduzido em LIMA, Jorge de. Poesia completa. Op. cit., p. 94. I7 D'HoRTA, Vera. "Preto no branco". In: A gravura de Lasar Segall. São Paulo: Museu Lasar Segall; Brasília: Ministério da Cultura/ sPHAN/Fundação Nacional PróMemória, ı988, p. xii. 
A Sinhá que, no começo, lhe dava ordens, termina por acusá-la de roubo. $O$ erotismo desponta no texto na relação da Fulô com a Sinhá e, mais adiante, com o Sinhô, que, ao vê-la nua, sendo espancada pelo Feitor, fica totalmente enfeitiçado e, na próxima oportunidade, vai ele mesmo sozinho açoitá-la. Porém o que acaba ocorrendo na ocasião é a traição à Sinhá. Os açoites, motivados pelas acusações da Sinhá de que a negra lhe roubara objetos "que teu Sinhô me mandou" mudam o rumo da história que termina com a constatação pela Sinhá de que a Fulô lhe roubara "teu Sinhô que nosso Senhor me mandou" o que comprova a habilidade do narrador na construção do texto e a habilidade da personagem em sua atuação.

O uso dos pronomes possessivos que constrói a hierarquia no texto - meu, teu, nosso - também indica a desestruturação da pirâmide ou a desobediência à hierarquia. A enunciação da posse dos objetos pela Sinhá dá lugar à perda do Sinhô pela Sinhá. Ao apropriar-se dos objetos, enviados pelo Sinhô à Sinhá, e do Sinhô enviado a esta pelo Senhor, comprova-se a desobediência de Fulô ao Sinhô e ao Senhor. Ao substituir o pronome "meu" pelo pronome "nosso" na referência ao Senhor, a Sinhá coloca-se em um único momento no mesmo patamar que a Fulô, pois Deus não pertence só a ela, é o Senhor de todos, independentemente da posição social. Ironicamente, a negra também se iguala a ela na relação com o Sinhô, pois passará a ocupar seu lugar na esfera da sexualidade:

Cadê meu frasco de cheiro

que teu Sinhô me mandou?

Cadê meu lenço de renda, cadê meu broche, meu cinto, cadê meu terço de ouro que teu Sinhô me mandou?

Cadê, cadê teu Sinhô que Nosso-Senhor me mandou?

A sensualidade que emerge do poema é assinalada por Antônio de Alcântara Machado:

Agora Essa negra Fulô. É das cousas mais marcantes que a poesia nordestina nos tem enviado de muito tempo para cá. Essa negra Fulô sim. Bole com a gente. Pinica a sen- 
sibilidade da gente. Embala o sensualismo da gente. Canção e história da escravidão sem querer ser. Poesia boa, cheirosa, suarenta, apetitosa, provocadora. ${ }^{18}$

De caráter predominantemente narrativo, as imagens ganham força com os recursos que constroem a musicalidade do texto: a medida regular dos versos, de seis ou sete sílabas; o ritmo marcado pela repetição de "Essa negra Fulô!" — que funciona como um refrão - e "Ó Fulô! Ó Fulô!" — que introduz alternadamente as estrofes - e do nome Fulô (corruptela de flor) no final de vários versos, quase sempre constituindo vocativo e compondo a rima que ecoa por todo o poema intercalada a outras; a anáfora e/ ou o paralelismo, presente em quase todas as estrofes. A epígrafe "Essa negra Fulô!/ Essa negra Fulô!" ${ }^{19}$ identificada como "Motivo de côco de Alagoas", introduz esse elemento da cultura popular regional como intertexto, ou subtexto, e reitera a importância do elemento musical. A oralidade e o discurso direto estruturam uma mise-en-scène.

O poema tem nas ilustrações de Segall o registro de suas passagens mais significativas. A primeira, que mostra Fulô penteando os cabelos da Sinhá, tem seu foco sobre a negra, de roupas simples e pés descalços, mostrada de corpo inteiro, de costas, com o rosto perfilado. A Sinhá é mostrada parcialmente, vêse apenas seu busto e seus cabelos longos. O espelho, que está diante delas, reflete o rosto de Fulô e, assim, realça sua importância na composição e sugere o que se confirmará no final do poema: a Fulô ocupa o lugar da Sinhá na relação com o Sinhô.

A segunda ilustração retrata a perplexidade do Sinhô diante da nudez de Fulô. Embora não seja possível ver seu rosto, tal perplexidade é percebida por seus gestos: as mãos erguidas na altura do tronco, bastante aumentadas, especialmente se contrastadas com a da Fulô, pequena e frágil, da qual se aproxima. Ao fundo, um recorte da janela e uma lamparina compõem o cenário no qual se destaca a negra em primeiro plano. Vista de frente, ela não dirige seu olhar a ele, que, ao contrário, está totalmente voltado para ela. Fica sugerido o desencontro, algo os separa. Ela está direcionada para um ponto fora do espaço limitado pelo desenho. A ausência do rosto do Sinhô e da Sinhá confirma o anonimato destes, que ocorre também no poema.

Vemos outro retrato em "Madorna de Iaiá" um poema escrito no "idioma afro-nordestino" O uso de expressões que podem ser assim caracterizadas, de versos curtos e de onomatopéias imprime musicalidade ao poema que tem como tema a descrição, por um observador indiscreto, do sono de Iaiá. Além de contar o que vê, ele tenta adivinhar sensaçōes, desejos, sonhos e, assim, cria
I8 MACHADO, Antônio de Alcântara. "Jorge de Lima - Poemas e Essa negra Fulô - Maceió 1927 e 1928" Revista de Antropofagia (São Paulo), p. 4, ano I, $n^{0}$ I, maio 1928.

I9 Eliminada nas ediçōes posteriores. 
uma atmosfera erótica. Tudo se desenvolve paralelamente à evocação da paisagem do nordeste e em um clima de intensa preguiça:

Iaiá está na rede de tucum.

A mucama de laiá tange os piuns,

balança a rede,

canta um lundum

tão bambo, tão molengo, tão dengoso,

que Iaiá tem vontade de dormir.

Com quem?

Ram-rem.

Para compor o cenário em que estão Iaiá e a mucama, além da visão, também são ativados a audição - por meio das onomatopéias e de verbos e substantivos relacionados ao universo sonoro - e o olfato - com a alusão ao cheiro de Iaiá, indiretamente relacionado à doçura do mel:

Mas que cheiro gostoso tem Iaiá!

Que vontade doida de dormir...

Com quem?

Cheiro de mel da casa das caldeiras!

O sagüim de Iaiá dorme num coco.

$[\cdots]$

Pára a mucama de cantar,

tange os piuns,

cala o ram-rem,

abre a janela,

olha o curral:

- um bruto sossego no curral!

Muito longe uma peitica faz si-dó...

si-dó... si-dó... si-dó... 
$\mathrm{Na}$ ilustração, temos, no primeiro plano, a Iaiá em sua rede, dormindo, em uma pose meio ingênua, meio sensual. No segundo plano, vemos a menina que balança a rede. Chama a atenção a semelhança física entre ambas, eliminandose na imagem a oposição entre a iaiá e a mucama. Ao fundo, reproduz-se a natureza, o que reforça a naturalidade do quadro observado, que o poema também transmite. A ilustração representa a imagem do poema de forma condensada.

Em oposição ao plural de vozes que caracteriza "Essa negra Fulô" o poema "Joaquina maluca" está construído como um monólogo. Composto por perguntas sem resposta, estruturado na função fática, tem um estilo prosaico e ingênuo. O eu poético tenta adivinhar os motivos da loucura da personagem, por isso faz perguntas. Destaca sua beleza, também inexplicável, e inocência e a aponta como vítima de um mundo, não descrito, que a levou à loucura. Mais do que na busca de explicações ou justificações, o poema consiste em um registro do que se vê. Sua estrutura básica é a negação, a qual, por extensão, pode ser considerada como motivo da loucura: a negação do mundo de forma geral e, mais especificamente, da crueldade de que foi e é vítima:

Joaquina Maluca, você ficou lesa

não sei porque foi!

Você tem um resto de graça menina,

na boca, nos peitos,

não sei onde é...

Joaquina Maluca, você ficou lesa,

não é?

Talvez pra não ver

o que o mundo lhe faz.

Você ficou lesa, não foi?

Talvez pra não ver o que o mundo lhe fez.

Joaquina Maluca, você foi bonita, não foi?

Você tem um resto de graça menina

não sei onde é...

Tão suja de vício, nem sabe o que foi.

Tão lesa, tão pura, tão limpa de culpa,

nem sabe o que é! 
Enquanto no poema não se evidencia o negrismo, na ilustração, vemos uma personagem negra, em primeiro plano, com uma expressão no rosto de interrogação e insanidade, gestos espontâneos e despreocupados e alheamento ao que a cerca. A seu redor, imagens pouco definidas representam-na em momentos passados, nua e sensual, como o eu lírico do poema provavelmente a conheceu. Constrói-se um contraste entre o que se vê e o que a memória guarda. Completam o retrato, a cama sobre a qual ela está e uma mesa com uma lamparina e outros objetos indefinidos.

"Joaquina maluca" dialoga com o poema anterior, mas a sensualidade que aflora em "Madorna de Iaiá" é substituída pelo "resto de graça menina" - a sensualidade passa a ser passado. Ao mesmo tempo, faz a ponte com "Pai João" que também apresenta o negro como vítima da sociedade.

"Pai João" constitui-se pela crueza e dureza na descrição de um escravo sofrido que está no fim da vida. Sua história é contada por seus feitos e também pela violência que sofreu - parcialmente responsável por sua destruição e morte - a qual se estendeu também a sua filha. O texto é uma representação metonímica da condição do escravo negro no Brasil, explorado e maltratado pelo branco. Constitui-se em uma denúncia sem meias-palavras, com o uso de metáforas e comparações que refletem o sofrimento sem nenhum atenuante, com ironia em algumas passagens:

Pai João secou como um pau sem raiz.

Pai João vai morrer.

[...]

A filha de Pai João tinha um peito de vaca para os filhos de Ioiô mamar.

Quando o peito secou a filha de Pai João também secou agarrada num ferro de engomar.

A pele de Pai João ficou na ponta dos chicotes.

A força de Pai João ficou no cabo da enxada e da foice.

A mulher de Pai João o branco

A roubou para fazer mucamas.

O sangue de pai João se sumiu no sangue bom

Como um torrão de açúcar bruto

Numa panela de leite. -

Pai João foi cavalo pra os filhos de ioiô montar. 
A referência à mestiçagem, nos versos acima, faz-se por meio da citação de um elemento do cotidiano, porém sua construção passa da sutileza à amargura. Apenas no final do poema, introduz-se certa doçura, que vem mesclada a uma grande tristeza:

Pai João sabia histórias tão bonitas que

Davam vontade de chorar

Pai João vai morrer.

Há uma noite lá fora como a pele de Pai João.

Nem uma estrela no céu.

Parece até mandinga de Pai João.

Observa-se que, no poema "Madorna de Iaiá" a descrição da jovem branca se faz com um vocabulário predominantemente afro, enquanto na descrição de Pai João, ao contrário, esses termos são minoria. Da mesma forma, a Iaiá que aparece na ilustração tem traços de negra e parece então ser representada, tanto no texto como na imagem, sob a perspectiva do negro, e não do branco.

A primeira ilustração de "Pai João" consiste na representação de sua filha amamentando uma criança, rodeada por outras crianças e em meio a folhas de árvores. Vemos apenas seu rosto e tronco, destacando-se seus seios no conjunto. Essa imagem sugere a continuidade da personagem central em seus descendentes. $\mathrm{Na}$ segunda ilustração, temos o rosto de Pai João no primeiro plano, de olhos fechados, sobreposto a uma série de imagens menores que representam seu passado: o trabalho, os açoites e a relação sexual com uma negra, que pode ser a imagem de seu papel como procriador ou de sua esposa roubada pelo branco. Forma-se um conjunto bastante carregado, com a sobreposição de cenas, que acaba contribuindo para a transmissão da idéia da opressão ao espectador/ leitor.

Vemos nesses retratos o negro em diferentes situações e conflitos em diversos momentos de sua trajetória. Completam-nos os rituais bem como os ambientes nos quais circulou, contemplados em outros poemas.

Ambos os artistas vinham dedicando-se a esse tema desde os anos vinte: Jorge de Lima, nos livros já mencionados e Lasar Segall em várias obras em que o elemento negro é central, como os óleos Mulata com criança, Bananal, Menino com lagartixas. Foi exatamente por ter conhecimento da produção anterior de Segall que Jorge de Lima encomendou-lhe as ilustrações.

Os retratos com palavras completam-se nas ilustrações a nanquim e vice- 

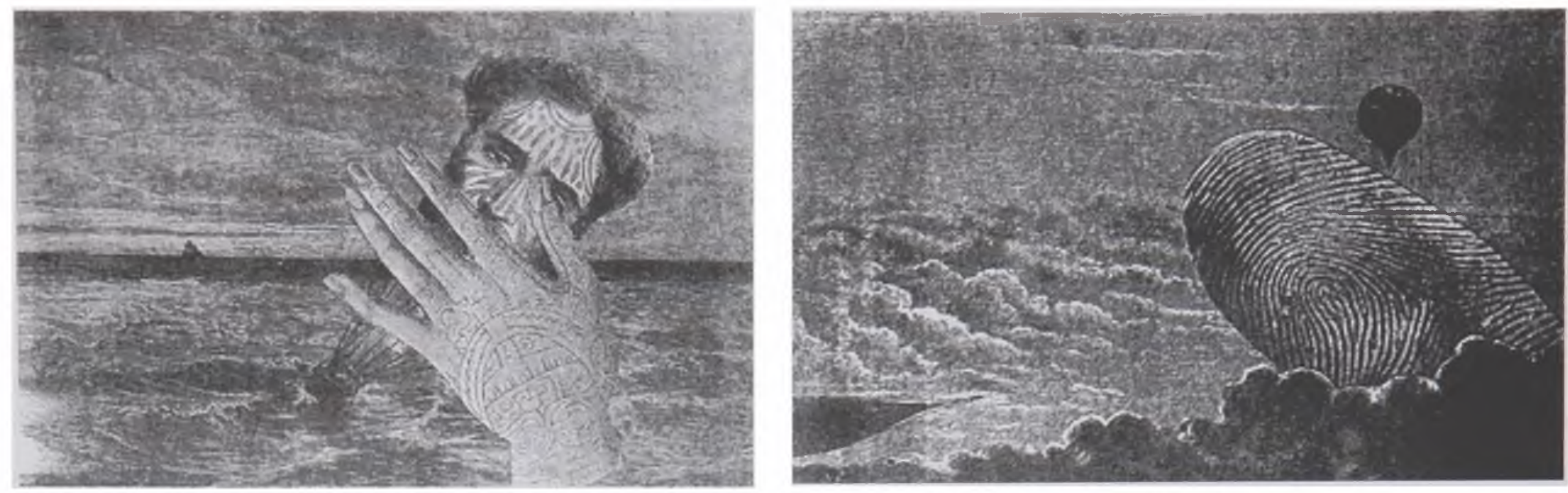

20 Embora Ana Maria

Paulino, em O poeta insólito [São Paulo: IEBUSP, I987, p. 4I], aponte como primeira publicação aquela realizada em $O$ Estado de São Paulo, no Suplemento em Rotogravura, em novembro de I939, encontramos publicações anteriores nos mencionados álbuns de recortes que integram o acervo da Fundação Casa de Rui Barbosa, das quais essa do jornal carioca é a mais antiga. versa. Confluem assim o olhar do brasileiro e o do estrangeiro em direção ao elemento estrangeiro incorporado à terra. A abolição dessas fronteiras envolve ao mesmo tempo a eliminação de outras igualmente móveis: entre as artes do tempo e do espaço, a poesia e o desenho. Os versos e os traços parecem prolongar-se um no outro ao retratar o universo negro.

\section{Poesia fotoplástica}

Ao realizar diversas fotomontagens visivelmente influnciadas pelos surrealistas, Jorge de Lima constituiu-se no precursor dessa atividade no Brasil. Embora esse trabalho só venha a ser publicado em livro em 1943 - A pintura em pânico, Rio de Janeiro: Ed. Revista Acadêmica - , o autor divulga-o com anterioridade em jornais e revistas desde o fim dos anos trinta.

O Cruzeiro, em uma edição de julho de $1938,{ }^{20}$ traz cinco "fotografias", assim denominadas pelo próprio autor na entrevista que acompanha as imagens, na qual aponta Max Ernst como o criador do gênero, explica como ele próprio as realiza e as compara a um poema, identificando-as como outra forma de expressão poética:

- Vocês vejam: cada fotografia dessas vale um poema, não vale? Pois é a intenção de Max Ernst. Com diversos elementos que isolados nada significam, produzir um conjunto que tem o dom de provocar uma sensação poética. [...] Max Ernst já reuniu suas fotografias em mais de um livro, todos de sucesso. Um desses livros se chama La femme 100 tête [...]

Ernst e seus seguidores chamam isso de gravuras supra-realistas — prossegue o 
poeta. Eu fiz fotografias com uma direção lírica e romântica. Como faço isso? Ora, muito simplesmente: pego uma porção de objetos, de coisas, de idéias, uma revista, um jornal, uma escultura, elementos que isolados não têm a menor significação. Junto e produzo alguma coisa que podemos chamar de um poema.

E, para concluir, Jorge de Lima nos vai expondo como faz cada uma de suas foto. grafias mais apreciadas:

- Esta, por exemplo, a que podemos chamar 'O último celerado nas nuvens'. Que elementos a compõem? Uma impressão digital, um fundo de céu cheio de nuvens e um balão. Uma impressão digital é, positivamente o que há de mais banal. Uma vista de céu cheio de nuvens também nada tem de extraordinária. O conjunto é uma sensação poética...

Dessas fotomontagens, quatro serão reproduzidas no livro mencionado. A única não republicada está acompanhada pelo título "Censura" e traz como legenda "Um homem seguro pelos preconceitos": uma grande mão segura um homem pela perna direita, como se fosse um boneco. Há nuvens ao fundo. O tamanho da mão causa impacto em contraste com o ser humano, muito menor, e representa a censura com força e beleza estética. Dialoga com uma fotomontagem publicada em A pintura em pânico, em que uma enorme mão, feminina e tatuada, se impõe sobre um rosto sem corpo que paira sobre a superfície (terra ou mar) e cobre especificamente um de seus olhos e sua boca. A frase que a acompanha é "A invenção da polícia", que reforça a idéia de censura e repressão.

Aquelas que serão incluídas no referido livro terão suas legendas/títulos, que o poeta atribui a todas, alteradas nessa ocasião. A fotomontagem comentada na entrevista, "O último celerado nas nuvens", passará a ser acompanhada pela frase "O criminoso lega sua impressão digital". O título anterior parecenos muito mais poético que esse, mais direto. O balão que se vê ao longe amplia a idéia de solidão e abandono. No conjunto, a solidão é latente e revela muita perspicácia a representação metonímica do criminoso pela impressão digital, imagem que remete também à idéia de identidade, autenticidade e analfabetismo, quando substitui a assinatura das pessoas em documentos. Mas a impressão digital sobre as nuvens converte-se em algo absolutamente gratuito, pois passa a ser inalcançável, inapreensível, quase invisível.

Em julho de I939, em Dom Casmurro, Jorge de Lima volta a divulgar suas novas experiências, mas desta vez são découpages - consistem no mesmo processo de realização que a fotomontagem, porém o material utilizado é a gravura:

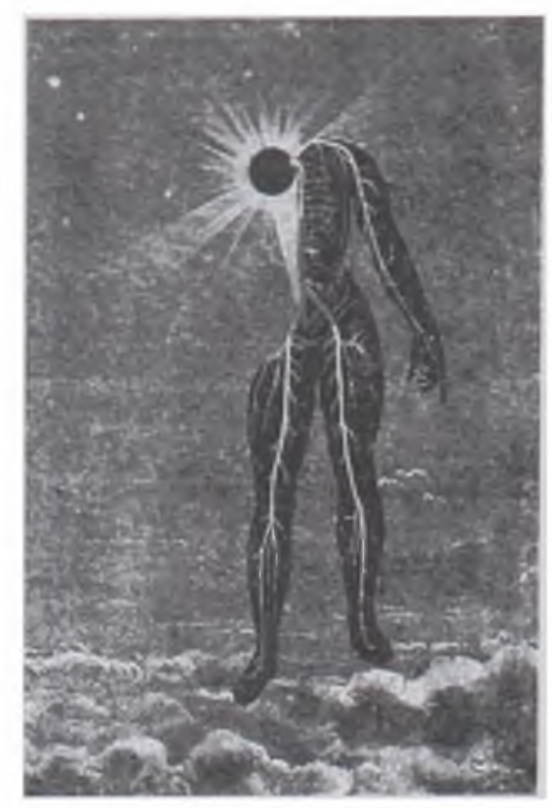

2I AMARal JR., Amadeu. "Jorge de Lima fotógrafo supra-realista". O Cruzeiro (Rio de Janeiro), p.12, 9.7.1938.

A ESQUERDA E ACIMA Fotomontagens de Jorge de Lima 
22 Bastos, Danilo. “A

découpage - processo

de gravura surrealista"

Dom Casmurro, Rio de Janeiro, 8.7.1939, s.p.

23 Ibidem.
[...] recortando e superpondo ou justapondo as gravuras mais diversas, às vezes gravuras que isoladas não têm nenhum valor didático, mas reunidas, em uma combinação simplesmente arbitrária deslancham verdadeiramente os mais surpreendentes poemas.

Por exemplo: esta figura banalíssima de um tratado qualquer de astronomia em conjunção com esta gravura de uma Anatomia sem importância nos dá uma impressão de germinação. Pois, não? E assim as outras: recorte, cole, ponha um dístico. É tão fácil como fazer um poema. Às vezes é necessário explicar... para atrapalhar mais ${ }^{22}$

É importante nesse texto a menção à existência de elementos surrealistas na obra de um pastor anglicano do século xviı I, Jung, autor de um poema intitulado "Pensamentos noturnos". o qual exerceu influência sobre a obra do poeta do Romantismo brasileiro Gonçalves de Magalhães, segundo Jorge de Lima. A partir dessa informação, aponta o Surrealismo e o Romantismo como constantes da poesia e, sendo assim, também integrantes de sua obra:

[...] o surrealismo como o romantismo são constantes do espírito humano: São João Evangelista no Apocalipse, os sonhos e as visões de Buda, Maomé, etc, Lautréamont no Chant [sic] de Maldoror, antes do suprarealismo foram notáveis suprarealistas.

$[\ldots]$

Suprarealismo, música, álcool, morfina, poemas, tudo isto são caminhos lícitos ou ilícitos para a poesia. São caminhos para atingir a poesia. Às vezes perigosos e proibidos pela polícia.

$[\ldots]$

Minha poesia, mesmo $O$ Anjo, não são suprarealistas. E o são pois como lhe disse: o suprarealismo como o romantismo são constantes da poesia. E a minha poesia é isto tudo ao mesmo tempo que mística, sensual, o que quiserem. $[\ldots]^{23}$

Das seis imagens que estão nessa publicação, apenas uma permanece inédita em livro: sob o título "Distância”. é formada pela visão do mar, à esquerda do qual se vê uma mão que escreve sobre uma folha de papel. Inverte-se a expectativa da corriqueira cena de lançar ao mar uma garrafa contendo uma mensagem escrita, visto que aqui é o mar que avança em direção ao papel, ameaçando apagar o que se escreve e talvez levar o papel em branco. A mão sem corpo sugere fragilidade e incorpora a distância que se quer superar por meio da escrita que está na iminência de ocorrer. Alude ao processo de criação, mas apresenta um escritor sem rosto, capaz de escrever em qualquer lugar, sobre qualquer paisagem. Poderia ter recebido o título "Criação poética" 
A fotomontagem que Jorge de Lima comenta na entrevista é de uma beleza ímpar e revela a extrema habilidade do artista. Ao fragmentar o corpo extraído de um livro de anatomia e colocar, no lugar de sua cabeça, um astro que emite luz, Jorge de Lima constrói um terceiro elemento: vemo-nos diante da imagem do ser, meio árvore, meio gente que acaba de brotar em meio ao universo, sobre nuvens, com o corpo em formação e a cabeça pendendo para a direita. $\mathrm{O}$ título "Germinação" por ele atribuído, reforça essa imagem, assim como a frase que a acompanhará na publicação posterior: "e as primeiras fecundações (contra todas as ordens)"

Ainda em I939, em novembro, são publicadas outras três fotomontagens no Suplemento em Rotogravura do jornal O Estado de São Paulo, acompanhadas por um texto de Mário de Andrade, intitulado "Fantasias de um poeta" Segundo Ana Maria Paulino, em O poeta insólito: fotomontagens de Jorge de Lima, o poeta alagoano enviou fotomontagens ao paulistano e este, então, tomou a iniciativa de divulgá-las. Integram o acervo de Mário de Andrade, hoje no IEB-USP, onze fotomontagens, as quais foram divulgadas nesse livro em 1987 , juntamente com o texto mencionado. ${ }^{24}$

Curiosamente, as três fotomontagens publicadas no Suplemento não integram o livro de Paulino; duas delas foram incluídas no livro de I943, e uma não voltou a ser publicada, a qual merece uma análise pela força que a imagem que a constitui encerra. Mário de Andrade refere-se a ela apenas brevemente, como "uma das invenções mais encantadoras de Jorge de Lima" Apesar da beleza do conjunto, a imagem da linda mulher deitada de bruços com uma maçã na boca é um pouco grotesca. Há outras frutas sobre seu rosto, uma folha faz as vezes de chapéu e ela, em seu sono, envolve com um dos braços a imagem de Saturno, a mesma que havia aparecido na fotomontagem anteriormente descrita. A serenidade da imagem é impressionante.

Em seu texto, Mário de Andrade descreve o processo de realização das fotomontagens e aponta diversas possíveis leituras: o que a princípio parece brincadeira revela-se "uma verdadeira arte, um meio novo de expressão" Aproxima-se da psicanálise, refere-se à expressão lírica, à revelação do artista que esta atividade proporciona e, ao comentar uma imagem, aponta características comuns ao poeta e ao realizador de fotomontagens: ${ }^{25}$

As nossas tendências mais recônditas, nossos instintos e desejos recalcados, nossos ideais, nossa cultura, tudo se revela nas fotomontagens. [...]

$[\ldots]$
24 Foram publicadas em A pintura em pânico três destas fotomontagens.

25 Essa imagem não integra $O$ poeta insólito, mas sim A pintura em pânico. 
26 ANDRADe, Mário de.

"Fantasias de um poeta". In: Paulino, Ana

Maria. Op. cit., p. 9.

27 Revista Renovação

(Recife), ano III, $\mathrm{n}^{\mathrm{o}} \mathrm{I}$, p. 8-II, jan. I94I.
[...] O temperamento místico e profundamente compassivo do poeta está perfeitamente expresso na mais simples dessas fotomontagens, a religiosa. Realmente nada mais sugestivo e impressionante que na aridez trágica desses morros pedrentos, a aparição assombrada, o grito prodigiosamente sofredor do Crucificado. Não se sabe se Ele vai surgindo em seu martírio ou se vai desaparecendo da terra, como se desaparecesse da memória dos homens... ${ }^{26}$

Como Mário de Andrade afirma, essa forma de expressão "não deve ser apenas uma variedade de poesia sobre-realista", "é uma espécie de introdução à arte moderna" "uma arte da luz, como a fotografia, o cinema e a pirotécnica"

Em janeiro de I94I, a publicação de quatro fotomontagens de Jorge de Lima na revista Renovação, de Recife, da qual Vicente do Rego Monteiro era um dos diretores, proporciona novo diálogo com outro artista brasileiro. Identificadas como "Poesia fotoplástica" ou "Imagem foto-poética" uma delas motivou o poema de Rego Monteiro La simili-méduse veille sur la ville, com a explicação entre parênteses "(Sur un motif de poésie plastique de Jorge de Lima)" ${ }^{27}$

A imagem da mulher-medusa que paira sobre a vista de uma cidade, formada por algumas colinas e diversas casas, é impactante. Seu rosto, com olhos brancos, sugere indefinição e mistério. Os tentáculos em que se metamorfoseiam seus cabelos sugerem mais ameaça do que proteção.

Motivado pela imagem, Vicente do Rego Monteiro, em seu poema, desfaz a impressão ameaçadora da mulher-medusa, substituindo-a por uma imagem erótica, maternal e poética, cujos tentáculos querem envolver a imensidão. Atribuindo-lhe cores, sons e movimentos, a medusa quase se converte em deusa que "vela sobre a cidade" cujos cabelos fazem sua ligação com a terra:

La simili-méduse à la blonde chevelure symphorisée, veille,

Sur la ville prolétaire qui se réveille.

Elle penche sur la terre ses flexibles rameaux,

Comme la main au coeur de cire des coteaux.

Elle voudrait de sa bouche retenir

L'harmonie des baisers à venir,

L'épave des sombres festins ne saurait lui suffire.

Elle donnerait son cou d'ivoire et tout empire,

Pour posséder dans le creux de sa main, l'immensité

Tendre et sonore où retentit la maternité,

Franc de port, d'emballage et d'enfance. 
Les débris d'oreilles sur l'espace immense

Écoutent le son de la lyre qui s'évapore,

Et que l'invisible auditeur voudrait écouter encore,

Puis, détachant un doigt de sa longue chevelure

Le jette à terre aux distraits d'aventure.

Rego Monteiro, tão ou mais plural do que Jorge de Lima, dedicou-se também à poesia e à pintura, embora com uma trajetória diversa, tendo-se dedicado inicialmente à pintura e só a partir dos anos 1940 à poesia. Com esse poema, constrói um duplo diálogo entre artes e artistas que tem continuidade na tradução para o francês do poema "O acendedor de lampiões", realizada por Monteiro e também publicada nessa revista. ${ }^{28}$

As fotomontagens publicadas em Renovação, com exceção da que motivou o poema de Rego Monteiro, integrarão o livro de que trataremos a seguir. Dentre as reproduzidas nos jornais e revistas citados, apenas uma se repete, o que comprova a intensa produção do autor, já que elas foram divulgadas em datas muito próximas.

A pintura em pânico é o ponto máximo desta produção. Reúne 4I fotomontagens, todas acompanhadas por títulos ou frases que constroem em alguns momentos uma narrativa ilustrada pelas imagens. Como as páginas não estão numeradas, qualquer percurso é válido para sua leitura e se pode estabelecer combinações diversas fazendo dialogar frases e imagens infinitamente.

O caráter revolucionário é antecipado por seu título. A atribuição da sensação de pânico à arte é uma transferência daquilo que ela poderia causar, ou do que a motiva, para a própria pintura. Segundo Murilo Mendes, no texto introdutório ao livro, "O pânico é muitas vezes necessário para se chegar à organização" Foi provavelmente com base nesse princípio que ele próprio intitulou A poesia em pânico seu livro de poemas publicado em I938, em cuja capa se reproduz uma fotomontagem. ${ }^{29}$

A introdução de Murilo Mendes aponta para a "desarticulação dos elementos" na construção das fotomontagens e para o parentesco dessa atividade com a fotografia e a pintura. A aproximação de elementos diversos já no processo, que consiste na aceitação do casual, do arbitrário, na aproximação da infância à idade madura - tudo isso é ressaltado em tom de manifesto:

Esta aliança da pintura e da fotografia permite e facilita o encontro do mito com o quotidiano, do universal com o particular.
28 "L'allumeur de révèrberes" Renovação (Recife), ano vi, Caderno de Poesia, s.p., fev. I944. 29 Esta fotomontagem integra também o livro A pintura em pânico $\mathrm{e}$ traz como título "A poesia em pânico". No livro de Murilo Mendes, a autoria da capa é atribuída a ele e a Jorge de Lima. 
A DIREITA

Fotomontagem

da capa de

A pintura em pânico

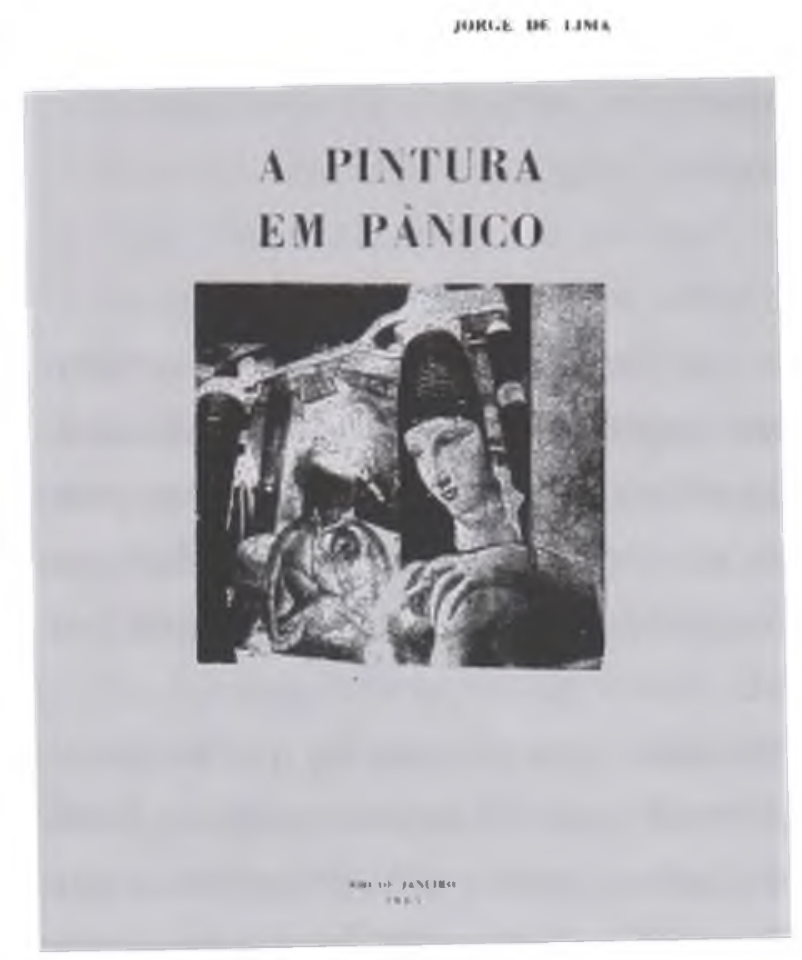

A PINTURA

EM PANICO

$[\ldots]$

Desmontar a burrice, o tabu dos materiais ricos, desarticular o espírito burguês em todos os seus setores, organizar a inteligência e a sensibilidade; atingimos enfim a inevitável transfiguração do elemento social e político. Movimentos paralelos: revolução política, revolução artística.

$[\ldots]$

Esta é a época visual. A luz elétrica obscureceu parcialmente o mundo, deixando muitos objetos e seres na penumbra. A fotomontagem de novo os ilumina.

Em seu conjunto, destacam-se a desconstrução dos corpos, a recorrência de mãos e cabeças que surgem em meio à paisagem: as mãos sugerem deuses ex machina que vêm interferir na ordem reinante; as cabeças parecem germinar, brotar do nada; ao mesmo tempo, alguns corpos têm a cabeça substituída por outros objetos, uma reversão que a ciência aliada à criação poética apresenta como possível.

A estes elementos, presentes também em algumas das imagens já comentadas, soma-se a recorrência de Saturno, o cronos na mitologia grega, deus do tempo. Alternando-se com referências à tradição católica, constrói um paralelo com Tempo e eternidade, livro de poemas de Jorge de Lima e Murilo Mendes, de I935, cujo tema central é a religiosidade. Também alguns 
versos de A túnica inconsútil e Anunciação e encontro de Mira-Celi dialogam com as imagens.

Estamos pois diante da "inquietante estranheza", com elementos que nos são familiares deslocados e recombinados. Isso nos provoca e leva ao questionamento da concepção e percepção da arte, deslocando outras fronteiras: entre a pintura e a fotografia, a collage e a découpage, o sonho e o real, o lógico e o arbitrário.

Mais uma vez, a imagem convoca a palavra, sejam os títulos que as acompanham, os poemas anteriores ou contemporâneos do artista, ou os textos de outros poetas como Mário de Andrade, Rego Monteiro e Murilo Mendes. A arte se apresenta como espaço de encontro.

\section{Pinceladas de poesia}

Nos anos quarenta, Jorge de Lima publicou poucas obras literárias, dedicou-se à fotomontagem e mais intensamente à pintura. Nesse período, além de realizar muitos quadros, participou também de exposições e teve seu trabalho como pintor amplamente divulgado na imprensa alagoana e carioca. ${ }^{30}$

Embora o poeta-pintor afirme dedicar-se à pintura antes até de iniciar-se na poesia,,$^{31}$ seu trabalho pictórico só passou a ser mais conhecido e comentado nessa época. Como já demonstrara quanto à poesia e à fotomontagem, Jorge de Lima tem conhecimento das áreas às quais se dedica, é um pintor atento aos movimentos, às tendências, às técnicas, às críticas e é também autocrítico com relação a suas telas:

- [...] Muitos críticos sem conhecimento de causa me chamaram de supra-realista, de futurista, etc. Nada disto. Tudo o que tenho feito é objetivo e essencialmente real, meio de conhecer, de investigar. No fim me torno sempre perplexo.

$[\ldots]$

- [...] Eu sou assim, ofereço motivos contra a minha pretensa pintura.

$[\ldots]$

- Pretensa porque para mim é uma suposta pintura, na realidade meio de disciplina, contenção objetiva para norma de vida artística. Na verdade não tenciono nenhum título, nenhum lugar dentro da festa da pintura. ${ }^{32}$

Quase todos os textos sobre a pintura deste artista iniciam-se destacando sua pluralidade, apontando a pintura como "mais uma" das diversas atividades às
30 A produção pictórica de Jorge de Lima é bastante significativa. $\mathrm{O}$ catálogo de sua exposição realizada em 1945 na Associação Brasileira de Imprensa, no Rio de Janeiro, enumera 52 obras. Para um estudo abrangente de sua pintura em diálogo com sua poesia, cf. PAULINo, Ana Maria. Jorge de Lima. São Paulo: Edusp, I995.

3I Cf. D'Alvarez, Martins. "A poesia não pára, é a vida". Dom Casmurro. Não temos a referência completa desse texto.

32 Entrevista publicada em Vamos ler!, Rio de Janeiro, 8.6.1944. A entrevista está incompleta, assim como a referência. 
33 Alguns ensaios foram publicados na fortuna crítica que integra a Poesia completa de Jorge de Lima, citada. Outros, divulgados em jornais, integram os ál. buns de recortes, citados. Para a referência completa, cf. "Bibliografia" In: ANDRADE, Gênese. Imagens eloqüentes, Op. cit. 34 Navarra, Ruben. "Vida Artística. As horas vagas do poeta" Correio da Manhã, Rio de Janeiro, 20.5.1945, s.p. quais ele se dedica. Estabelecem relações entre suas obras pictórica e literária, apontam elementos plásticos em sua poesia e destacam o caráter onírico, memorialístico e autobiográfico do conjunto de sua obra. ${ }^{33}$

Ruben Navarra compara a poesia e a pintura de Jorge de Lima, considerando a segunda como um prolongamento da primeira e valorizando ambas:

[...] Não devemos recear uma aproximação, que chega a ser identificação, entre o poeta e o pintor, no caso de Jorge de Lima. Nele, o dom poético é o primeiro motor de sua atividade criativa, e disso vem aquela atmosfera de sonho das suas figuras, mesmo quando retratadas. [...] A verdadeira arte tem que nascer de uma fecundação poética. A visão artística é um sonho, ou não passa de um exercício estéril. [...] Essa tensão poética dentro da imagem plástica é o que livra Jorge de Lima de cair no acadêmico banal com a enorme facilidade que ele tem para o desenho. De maneira que, ainda nesse terreno, é a poesia que lhe enriquece a pintura. [...] Não estamos diante de um homem que pretenda vaguear no abstrato nem fazer demonstrações de material culinário. Sua pintura prolonga sua poesia, é verdade, mas concretiza e não apenas evoca. [.... $]^{34}$

De forma geral, em sua obra pictórica, encontramos elementos surrealistas, cubistas, religiosos e realistas, com o predomínio do caráter onírico.

O cubismo aparece na geometrização das figuras que compõem a tela $\mathrm{Vi}$ tral, de I947. No primeiro plano, uma mulher de frente, com o rosto perfilado, segura uma flor. Duas mulheres imediatamente atrás, uma à esquerda e outra à direita, também têm os rostos perfilados, direcionados para o centro. As linhas que definem o vitral constroem ângulos nos rostos e corpos. Sombrios, de olhos fechados, juntamente com os círculos que compõem o fundo, a auréola da figura central, constroem a atmosfera religiosa.

Cavalos alados, de 194I, caracteriza-se pelo surrealismo, como outras telas desse período. Em uma atmosfera de sonho, dois cavalos brincam no ar, sobre um fundo azul, composto também por cactos enormes e escuros e plantas coloridas, no primeiro plano, que intensificam a surrealidade do conjunto.

Em Pássaros e flores, de I94I, o surrealismo não constrói o onírico, mas o pânico: em um grande jarro, as flores se metamorfoseiam em pássaros que se agigantam e transbordam pela tela. $O$ tom avermelhado, cor de fogo, faz o quadro gritante e quase ameaçador.

Iemanjá, do mesmo ano, é uma representação surrealista da divindade da religião de origem africana, que nos remete aos poemas negristas, escritos no final dos anos I920 e nos anos I930. Seu corpo, sua longa cauda e seus enormes cabe- 


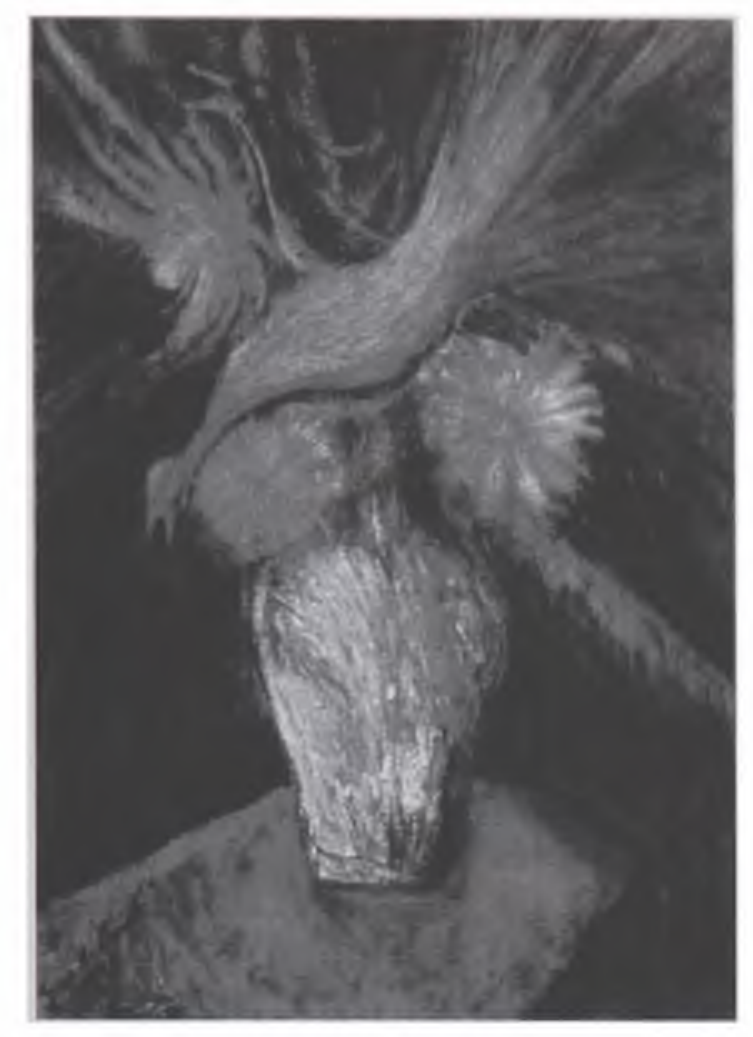

los são verdes como o mar do qual ela emerge e que parece prolongar-se nela. Seus braços, rosto e cocar rosados têm continuidade na pincelada rosa que colore o céu alaranjado. Com os olhos baixos e gestos sensuais, a tela também se aproxima do naïf, para o qual contribuem os peixinhos coloridos que a cercam.

A essa tela assemelha-se Menina e peixes. Seus cabelos resultam da metamorfose de um peixe sobre sua cabeça, assim como naquela os cabelos eram um prolongamento do mar. A cor vermelha do peixe, tanto o mencionado como o que ela traz no colo, na altura dos seios, permite ver no quadro uma alusão à sexualidade.

Duas mulheres e violino, de I942, e Três anjos, sem data, constituem-se também por figuras femininas representadas sob o viés surrealista. Três anjos, com uma atmosfera de sonho em que predomina o tom azul, tem intenso movimento conseguido por meio da pincelada e da posição das figuras com direcionamentos opostos: uma para a direita, com cabelos esvoaçantes; as demais para a esquerda, mas com as vestes acompanhadas por linhas que constroem o movimento da esquerda para a direita.

O movimento que caracteriza Três anjos intensifica-se em A cabeleira plástica, de I950, em que novamente três mulheres estão retratadas. Preocupadas com seus cabelos, duas erguem os braços, direcionando os rostos, vazios, sem expressão, para pontos diversos, enquanto a outra se curva. Suas formas arre- 
35 Ele fez ainda naturezas-mortas bastante significativas.

36 Cf. "Jorge de Lima visto por Jorge de Lima". Leitura (Rio de Janeiro), mar. 1943. Apud IIMA, Jorge de. Poesia completa. Op. cit., p. 35-7. dondadas imprimem sexualidade ao conjunto, contrastam com as linhas retas das formas que compõem o fundo, no sentido diagonal, e contribuem para projetar a imagem predominantemente para cima. Também é importante mencionar a conotação sexual que os cabelos encerram.

As telas de temática religiosa concentram-se nos anos quarenta: Crucificação (1) e São Jorge, de I944; Profeta bíblico, de 1947; Cristo, de 1948, e Crucificação (2), de I949.

Nas duas obras cujo título é Crucificação, vêem-se mulheres desesperadas, ajoelhadas diante da cruz. A primeira, em que predomina a cor marrom, é construída por diagonais que direcionam os movimentos para baixo, acompanhando o movimento do corpo de Cristo que pende da cruz, ao mesmo tempo que as mulheres erguem os braços, instaurando a tensão na imagem.

Na segunda, Cristo está mais ereto, mas sua cabeça pende para baixo. A mulher ajoelhada diante dele pende a cabeça totalmente para trás e olha para o espectador, criando-se um contraponto entre os dois rostos. O fundo vermelho, ladeado por morros ou rochas negras, intensifica a atmosfera de morte que se constrói com o corpo cadavérico de Cristo, esqueleto à mostra, e o traje negro da mulher que o acompanha, que se junta às rochas. Nessa tela, ao contrário da anterior, nota-se a ausência do movimento.

Observa-se a variação de temas e técnicas na pintura de Jorge de Lima. ${ }^{35} \mathrm{As}$ telas surrealistas mencionadas são uma continuidade do trabalho com as fotomontagens; as de tema religioso dialogam com seus poemas, da mesma época, de igual temática. É possível ainda encontrar correspondências entre as figuras femininas criadas em ambas linguagens.

É muito interessante constatar não só a inter-relação entre texto e imagem, como também entre as próprias telas que evocam uma a outra todo o tempo, seja pelo tema ou pela semelhança entre as figuras.

Ao refletir sobre sua obra, Jorge de Lima menciona sua necessidade de expressar-se em várias linguagen ${ }^{36}$ e aponta a pintura como complemento de sua poesia. ${ }^{37}$

\section{Entre o poeta e o pintor}

Ao transitar pelas diversas artes, deslocar fronteiras e construir obras que se inserem em mais de um campo, Jorge de Lima situa-se como poeta-pintor e pintor-poeta. 
Impossível dizer se a pintura complementa sua poesia ou o contrário, quando as palavras poéticas constroem imagens e as obras visuais "concretizam" os poemas.

Entre o espaço da página e da tela, a caneta e o pincel, as artes do tempo e do espaço, ele traça linhas que as unem em um diálogo ininterrupto.

"A linguagem/ parece outra/ mas é a mesma/ tradução", como dizem os versos de Invenção de Orfeu, reinvenção de sua própria obra que a engloba e transcende.

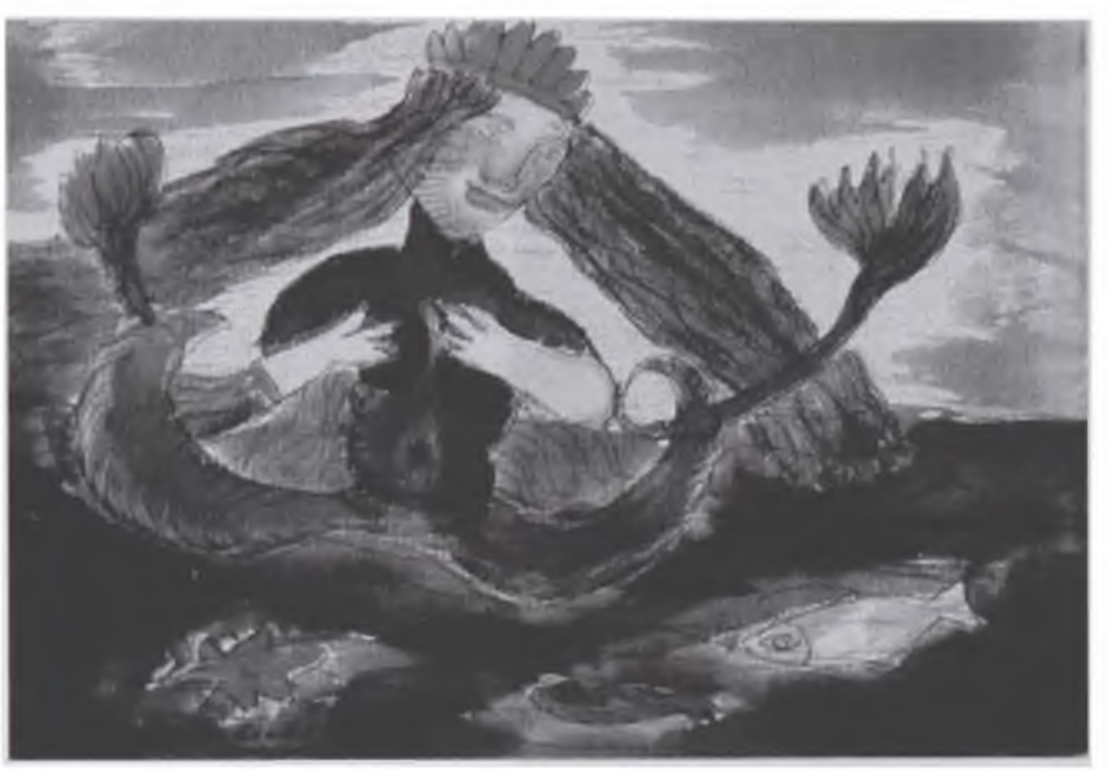

Gênese Andrade é mestre e doutora em Língua Espanhola e Literaturas Espanhola e Hispano-Americana pela usp. Autora de Composição e decomposição nas artes (Escolas Associadas, 2002), entre outros.
37 Cf. PACHECO, Armando. "Jorge de Lima defende sua poesia e sua pintura da pecha de herméticas". Vamos ler! Rio de Janeiro, I.II.I945. Reproduzido em lima, Jorge de. Poesia completa. Op. cit., p. 49-50, sob o título "Poesia e pintura".

\footnotetext{
A ESQUERDA

Jorge de Lima, lemanjá, tinta de caneta, guache e lápis de cor sobre papel, 1941.
} 


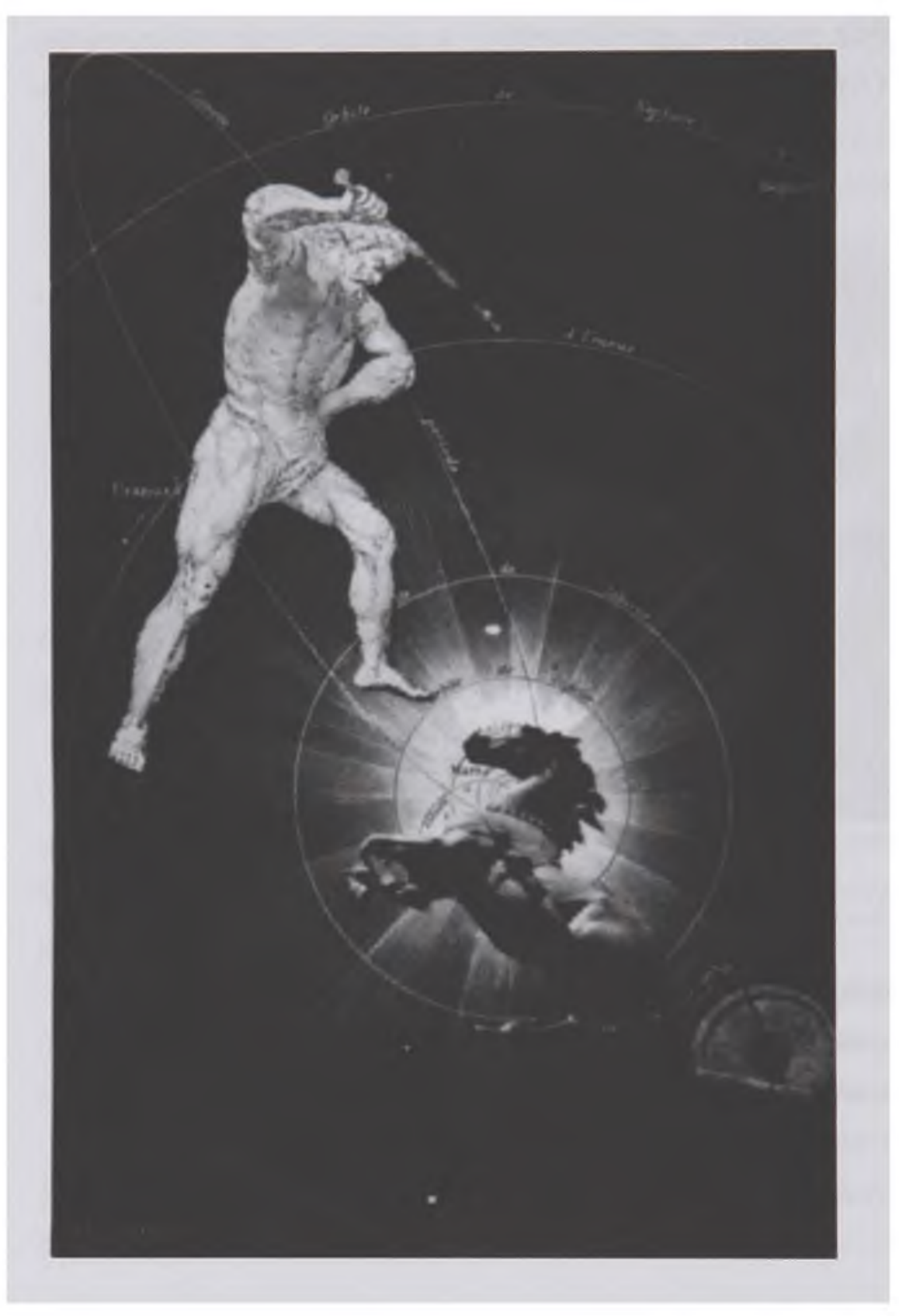

